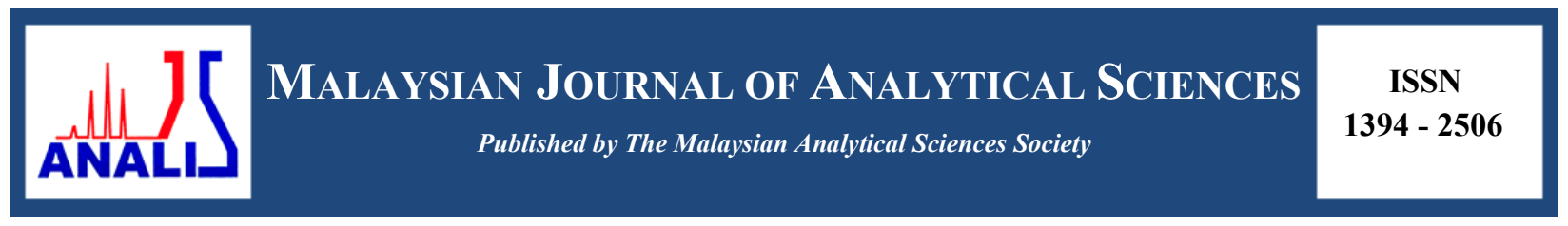

\title{
RADIOLOGICAL RISK ASSESSMENT FROM THE INTAKE OF VEGETABLES AND FRUITS IN MALAYSIA
}

\author{
(Penilaian Risiko Radiologi dari Pengambilan Sayur-Sayuran dan Buah-Buahan di Malaysia) \\ Wahmisari Priharti and Supian Bin Samat* \\ School of Applied Physics, Faculty of Science and Technology, \\ Universiti Kebangsaan Malaysia, 43600 UKM Bangi, Selangor, Malaysia \\ *Corresponding author: sbsamat@ukm.edu.my
}

Received: 3 May 2016; Accepted: 3 August 2016

\begin{abstract}
The activity concentration of natural radionuclides ${ }^{226} \mathrm{Ra},{ }^{232} \mathrm{Th}$ and ${ }^{40} \mathrm{~K}$ in vegetables and fruits in central zone of Malaysia were measured using gamma spectrometry. This is for the purpose of assessing the radiological risk in term of ingestion dose and cancer risk. The total ingestion dose from the consumption of vegetables were found to be $0.469 \pm 0.003,0.326 \pm 0.005$ and $0.232 \pm 0.003 \mathrm{mSv} / \mathrm{y}$ for infants, children and adults respectively. Whereas the total ingestion dose from the consumption of fruits for infants, children and adults were $0.349 \pm 0.005,0.283 \pm 0.007$ and $0.195 \pm 0.004 \mathrm{mSv} / \mathrm{y}$ respectively. The estimated cancer risk from the consumption of vegetables and fruits were $8.13 \times 10^{-4}$ and $6.83 \times 10^{-4}$ respectively for adults. The results obtained for activity concentration, dose and risk were found to be below the internationally recommended level. This indicates that the vegetables and fruits consumed in Malaysia would not pose any significant radiological impact to the population.
\end{abstract}

Keywords: activity concentration, gamma spectrometry, ingestion dose, natural radionuclides, risk assesment

\begin{abstract}
Kepekatan aktiviti radionuklid semulajadi ${ }^{226} \mathrm{Ra},{ }^{232} \mathrm{Th}$ and ${ }^{40} \mathrm{~K}$ dalam sayur-sayuran dan buah-buahan di Malaysia bahagian tengah telah diukur menggunakan spektrometer gama. Ini bertujuan untuk menilai risiko radiologi dalam istilah dos dimakan dan risiko kanser. Didapati jumlah dos dimakan dari pengambilan sayur-sayuran adalah $0.469 \pm 0.003,0.326 \pm 0.005$ and $0.232 \pm$ $0.003 \mathrm{mSv} /$ tahun masing-masing bagi bayi, kanak-kanak dan dewasa. Manakala jumlah dos dimakan dari pengambilan buahbuahan bagi bayi, kanak-kanak dan dewasa adalah masing-masing $0.349 \pm 0.005,0.283 \pm 0.007$ and $0.195 \pm 0.004 \mathrm{mSv} / \mathrm{tahun}$. Risiko kanser dari pengambilan sayur-sayuran dan buah-buahan bagi orang dewasa masing-masing dijangkakan sebanyak $8.13 \times$ $10^{-4}$ dan $6.83 \times 10^{-4}$. Kesemua hasil yang diperolehi dalam kajian ini bagi kepekatan aktiviti, dos dan risiko didapati berada di bawah aras yang dibenarkan oleh badan antarabangsa. Ini menunjukkan bahawa sayur-sayuran dan buah-buahan yang diambil di Malaysia tidak menimbulkan bahaya radiologi yang ketara terhadap manusia.
\end{abstract}

Kata kunci: kepekatan aktiviti, spektrometer gama, dos dimakan, radionuklid semula jadi, penilaian risiko

\section{Introduction}

The total annual radiation dose received by a member of the population each year is $3.01 \mathrm{mSv}$. About $79.73 \%$ of this number is contributed by natural radiation sources $(2.4 \mathrm{mSv} / \mathrm{y})$ and the rest $20.27 \%$ by man-made radiation sources $(0.61 \mathrm{mSv} / \mathrm{y})$ [1]. It is clear that the natural radiation sources is the main contributor to the total annual radiation dose. One component of this natural radiation sources is the ingestion dose $(0.29 \mathrm{mSv} / \mathrm{y})$ that are mainly contributed by ${ }^{238} \mathrm{U}$ and ${ }^{232} \mathrm{Th}$ series $(0.12 \mathrm{mSv} / \mathrm{y})$ and ${ }^{40} \mathrm{~K}(0.17 \mathrm{mSv} / \mathrm{y})$ [2]. 
Ingestion dose was received by human beings from the consumption of food contaminated with different radionuclides [3]. One of important food that can contributes to better health of human is vegetables and fruits [4]. According to Ministry of Health Malaysia, vegetables and fruits are categorized into the most second important food after rice and grains. Therefore, it is recommended to take these kind of food for at least 5 servings a day (approximately $400 \mathrm{~g} / \mathrm{d}$ ) [5].

Since the amount of recommended intake is quite big, it is important to monitor the radiological effect from the consumption of vegetables and fruits. This matter has become a great concern as has been reported by many researchers in different part of the world. From eleven different countries, 58 types of vegetables have been studied with seven common types namely spinach, carrot, cucumber, tomato, pumpkin, green bean and potato [6-16]. However in Malaysia, only 16 types of vegetables have been studied with spinach and cucumber as the common type $[17,18]$. Studies conducted in ten different countries reported that 26 types of fruits have been studied with eight common types namely apple, pear, orange, mango, banana, papaya, grapes and watermelon [6-16]. Whereas in Malaysia, only nine types of fruits have been studied i.e. apple, orange, mango, banana, papaya, star fruit, pineaple, rambutan and durian [17].

The present work is intended to (a) to determine the activities of ${ }^{226} \mathrm{Ra},{ }^{232} \mathrm{Th}$ and ${ }^{40} \mathrm{~K}$; (b) to assess the ingestion doses (due to these three radionuclides) incurred to the infants (1-2 years), children (7-12 years) and adults ( $>17$ years), (c) to compare these activities and doses with the previous local and international results, and (d) to estimate the consequent health risk due to the presence of those radionuclides in the vegetables and fruits. This work is also conducted to complete the precedent researches carried out by the authors on some food products such as milk and water $[19,20]$.

\section{Sample collection}

\section{Materials and Methods}

Twelve different samples of commonly eaten vegetables and fruits were collected. All the samples were purchased from the local market in central zone of Malaysia. All vegetables and three fruits sample (banana, papaya and mango) were locally produced in Malaysia whereas the remaining three fruits sample i.e. apple, orange and pear were imported from China, Korea and Australia respectively.

\section{Sample preparation}

All vegetables and fruits samples were prepared following the IAEA procedure [21]. They were made into powder to follow the geometry of standard silica powder $(4 \mathrm{~cm}$ height in $10 \mathrm{~cm}$ polyethilene beaker). First, they were washed and minced to get a small size. The unused part such as skin and seeds were discarded. Samples were then oven dried at $80{ }^{\circ} \mathrm{C}$ for 48 hours or until they reached constant mass. The dried sample were pulverized and sieved until they become $500 \mu \mathrm{m}$ homogen powder. The powdered samples were then kept in a sealed tight polyethilene beaker for 30 days to achieve secular equilibrium. For every types of samples, three samples were prepared to obtained the average activity concentration. This means, 36 samples $(=12 \times 3$ samples $)$ has been prepared for these two categories of samples.

\section{${ }^{226} \mathrm{Ra},{ }^{232} \mathrm{Th}$ and ${ }^{40} \mathrm{~K}$ measurement}

The radionuclides ${ }^{226} \mathrm{Ra},{ }^{232} \mathrm{Th}$ and ${ }^{40} \mathrm{~K}$ count, $N$ in the vegetables and fruits sample were measured using gamma ray spectrometry system with high purity germanium detector (HPGe). The detector was connected to MCA card (Accuspec B) and Genie-2000 analysis software. The detector energy resolution was $1.8 \mathrm{keV}$ at $1.33 \mathrm{keV}$ of ${ }^{60} \mathrm{Co}$ gamma ray peak and the relative efficiency was $30 \%$ at the same energy peak [22]. Each measurement was carried out for 43,200 second (12 hours). The count of each radionuclides were resulted from the line energy peaks emited directly by the corresponding radionuclide $\left(1460 \mathrm{keV}\right.$ for $\left.{ }^{40} \mathrm{~K}\right)$ or by the radionuclides daughter $(352$ and $609 \mathrm{keV}$ for ${ }^{226} \mathrm{Ra}$ and 239,583 and $911 \mathrm{keV}$ for ${ }^{232}$ ) [17]. The equation 1 used to calculate the activity concentration, $A$ and its uncertainty was expressed below [21,23]:

$$
A=\frac{N}{\varepsilon \times t \times P_{\gamma} \times M_{S}}
$$


where $\varepsilon$ is the detector efficiency, $t$ is measurement time, $P_{\gamma}$ is the $\gamma$-ray emission probability (\%) and $M_{\mathrm{s}}$ is the mass of the sample $(\mathrm{kg})$. To conceal the minor photopeaks for each sample, the minimum detectable activity (MDA) was calculated using the formula originally defined by Currie [24].

$$
\mathrm{MDA}=\frac{2.71+4.66 \sigma}{t \times \varepsilon \times P_{\gamma}}
$$

where $\sigma$ is the uncertainty of background count. The present measuring system recorded the MDA of $0.30,0.34$ and $2.88 \mathrm{~Bq} / \mathrm{kg}$ for ${ }^{226} \mathrm{Ra},{ }^{232} \mathrm{Th}$ and ${ }^{40} \mathrm{~K}$ respectively.

\title{
Dose and risk calculation
}

From the ${ }^{226} \mathrm{Ra},{ }^{232} \mathrm{Th}$ and ${ }^{40} \mathrm{~K}$ activities, the ingestion dose $D(\mathrm{mSv} / \mathrm{y})$ can be calculated using the following relationship (equation 3) [25]:

$$
D=A \times I \times E
$$

where $I(\mathrm{~kg} / \mathrm{y})$ is the annual intake of the vegetables and fruits [26] and $E(\mathrm{~Sv} / \mathrm{Bq})$ is the ingestion dose conversion factor of the radionuclide [27]. The values of $I$ and $E$ for the three age categories are given in Table 1 . The dose contributed from three radionuclides ${ }^{226} \mathrm{Ra},{ }^{232} \mathrm{Th}$ and ${ }^{40} \mathrm{~K}$ were summed to obtain the total dose, $D_{T}$. If it is assumed that the life-span of an average individual, $L$ is 70 years $[28,29]$ and the the cancer risk factor for low doses, $R F$ is 5 $\times 10^{-5}(1 / \mathrm{mSv})[1]$, the cancer risk $R$ can be estimated from:

$$
R=D_{T} \times L \times R F
$$

Table 1. The annual intake, $I$ and the ingestion dose conversion factor, $E$ for infants, children and adults

\begin{tabular}{lccllccc}
\hline \multirow{2}{*}{ Age Category } & \multicolumn{2}{c}{$\boldsymbol{I}(\mathbf{k g} / \mathbf{y})$} & & \multicolumn{3}{c}{$\boldsymbol{E}\left(\times \mathbf{1 0}^{-\mathbf{8}} \mathbf{S v} / \mathbf{B q}\right)$} \\
\cline { 2 - 3 } \cline { 6 - 8 } & Vegetables & Fruits & & & ${ }^{226} \mathbf{R a}$ & ${ }^{232} \mathbf{T h}$ & ${ }^{\mathbf{4 0}} \mathbf{K}$ \\
\hline Infants (1-3 years) & 12.96 & 23.01 & & 96 & 45 & 4.20 \\
Children (7-12 years) & 25.92 & 46.02 & & 80 & 29 & 1.30 \\
Adults (> 17 years) & 38.88 & 69.03 & & 28 & 23 & 0.62 \\
\hline
\end{tabular}

\begin{abstract}
Results and Discussion
The measured activity concentration, $A$ of ${ }^{226} \mathrm{Ra},{ }^{232} \mathrm{Th}$ and ${ }^{40} \mathrm{~K}$ in six samples of vegetables and six samples of fruits, their ranges and their average values were shown in Table 2. It was shown that the activity concentration in some samples of vegetables and fruits were not detectable. For vegetables, the detected activity concentration ranged from $0.60 \pm 0.57$ to $5.64 \pm 0.65 \mathrm{~Bq} / \mathrm{kg}$ for ${ }^{226} \mathrm{Ra}, 0.41 \pm 0.32$ to $4.40 \pm 0.49 \mathrm{~Bq} / \mathrm{kg}$ for ${ }^{232} \mathrm{Th}$ and $398.85 \pm$ 6.89 to $1072.59 \pm 10.25 \mathrm{~Bq} / \mathrm{kg}$ for ${ }^{40} \mathrm{~K}$. The average activity concentration of ${ }^{226} \mathrm{Ra},{ }^{232} \mathrm{Th}$ and ${ }^{40} \mathrm{~K}$ were found to be $1.38 \pm 0.21,1.06 \pm 0.12$ and $791.51 \pm 3.66 \mathrm{~Bq} / \mathrm{kg}$ respectively. For fruits, the detected ${ }^{226} \mathrm{Ra}$ activity concentration ranged from $0.90 \pm 0.64$ to $3.83 \pm 0.56$ with an average value of $1.22 \pm 0.17,{ }^{232} \mathrm{Th}$ activity concentration ranged from $0.56 \pm 0.48$ to $2.22 \pm 0.38$ with an average value of $0.77 \pm 0.12$ and the ${ }^{40} \mathrm{~K}$ activity concentration ranged from $75.39 \pm 4.78$ to $651.64 \pm 9.75$ with an average value of $288.63 \pm 2.83$, all in $\mathrm{Bq} / \mathrm{kg}$.
\end{abstract}

For both types of sample, the highest activity concentration were found to be ${ }^{40} \mathrm{~K}$ followed by ${ }^{226} \mathrm{Ra}$ and ${ }^{232} \mathrm{Th}$. This same pattern has also been reported by many previous work as shown in Table 3 . The activity concentration of previous results for vegetables samples ranged from 0.049 to $48.80,0.001$ to 25.36 and 0.79 to $1190.45 \mathrm{~Bq} / \mathrm{kg}$ for ${ }^{226} \mathrm{Ra},{ }^{232} \mathrm{Th}$ and ${ }^{40} \mathrm{~K}$ respectively. For fruits samples, they ranged from 0.009 to $8.15,0.001$ to 32.30 and 20.94 to 439.53 for ${ }^{226} \mathrm{Ra},{ }^{232} \mathrm{Th}$ and ${ }^{40} \mathrm{~K}$ respectively. In comparison with this range, the present results are in agreement with the previous results. This is because all the averaged value of the present results lie clearly within the range of the previous results. 
Priharti et al: RADIOLOGICAL RISK ASSESSMENT FROM THE INTAKE OF VEGETABLES AND FRUITS IN MALAYSIA

Table 2. ${ }^{226} \mathrm{Ra},{ }^{232} \mathrm{Th}$ and ${ }^{40} \mathrm{~K}$ measured activity concentration, $A$ from vegetables and fruits

\begin{tabular}{llccc}
\hline \multirow{2}{*}{ Sample } & Name & \multicolumn{3}{c}{ Activity concentration, $\boldsymbol{A} \pm \Delta \boldsymbol{A}(\mathbf{B q} / \mathbf{k g})$} \\
\cline { 3 - 5 } & & ${ }^{\mathbf{2 2}} \mathbf{R a}$ & ${ }^{\mathbf{2 3 2}} \mathbf{T h}$ & ${ }^{\mathbf{4 0}} \mathbf{K}$ \\
\hline Vegetables & Spinach & $5.64 \pm 0.65$ & $4.40 \pm 0.49$ & $998.04 \pm 9.13$ \\
& Carrot & $\mathrm{ND}^{\mathrm{a}}$ & $\mathrm{ND}$ & $398.85 \pm 6.89$ \\
& Broccoli & $1.29 \pm 0.62$ & $\mathrm{ND}$ & $664.54 \pm 8.75$ \\
& Pumpkin & $\mathrm{ND}$ & $0.41 \pm 0.32$ & $682.90 \pm 6.92$ \\
& Tomato & $0.76 \pm 0.63$ & $\mathrm{ND}$ & $932.11 \pm 11.02$ \\
& Cucumber & $0.60 \pm 0.57$ & $1.55 \pm 0.44$ & $1072.59 \pm 10.25$ \\
& Range & $0.60-5.64$ & $0.41-4.40$ & $398.85-1072.59$ \\
Fruits & Average & $2.07 \pm 0.31^{\mathrm{b}}$ & $2.12 \pm 0.24^{\mathrm{b}}$ & $791.51 \pm 3.66$ \\
& Apple & $2.58 \pm 0.58$ & $1.84 \pm 0.42$ & $151.49 \pm 5.69$ \\
& Banana & $\mathrm{ND}$ & $\mathrm{ND}$ & $401.59 \pm 5.85$ \\
& Orange & $\mathrm{ND}$ & $\mathrm{ND}$ & $279.74 \pm 7.70$ \\
& Pear & $3.83 \pm 0.56$ & $2.22 \pm 0.38$ & $75.39 \pm 4.78$ \\
& Papaya & $0.90 \pm 0.64$ & $0.56 \pm 0.48$ & $651.64 \pm 9.75$ \\
& Mango & $\mathrm{ND}$ & $\mathrm{ND}$ & $171.95 \pm 6.61$ \\
& Range & $0.90-3.83$ & $0.56-2.22$ & $75.39-651.64$ \\
& Average & $2.44 \pm 0.34^{\mathrm{b}}$ & $1.54 \pm 0.25^{\mathrm{b}}$ & $288.63 \pm 2.83$ \\
\hline
\end{tabular}

${ }^{a} \mathrm{ND}=$ Not detectable (MDA for ${ }^{226} \mathrm{Ra},{ }^{232} \mathrm{Th}$ and ${ }^{40} \mathrm{~K}$ were $0.30,0.34$ and $2.88 \mathrm{~Bq} / \mathrm{kg}$ respectively). ${ }^{\mathrm{b}}$ Due to the ND, respectively two and three out of $\operatorname{six}{ }^{226} \mathrm{Ra}$ and ${ }^{232} \mathrm{Th}$ activities of vegetables and respectively three and three out of six ${ }^{226} \mathrm{Ra}$ and ${ }^{232} \mathrm{Th}$ activities of fruits were undetected. Therefore, this average was calculated from detected values only.

Table 3. The measured activity concentration, $A$ in vegetables and fruits in comparison with the previous reported values

\begin{tabular}{|c|c|c|c|c|c|c|}
\hline \multicolumn{6}{|c|}{ Activity concentration $(\mathrm{Bq} / \mathbf{k g})$} & \multirow{3}{*}{$\begin{array}{l}\text { Country } \\
\text { [References] }\end{array}$} \\
\hline \multicolumn{3}{|c|}{ Vegetables } & \multicolumn{3}{|c|}{ Fruits } & \\
\hline${ }^{226} \mathrm{Ra}$ & ${ }^{232} \mathrm{Th}$ & ${ }^{40} \mathrm{~K}$ & ${ }^{226} \mathrm{Ra}$ & ${ }^{232} \mathrm{Th}$ & ${ }^{40} K$ & \\
\hline- & - & 93.29 & - & - & 86.93 & Spain [6] \\
\hline- & - & 0.79 & - & - & 34.91 & Syria [7] \\
\hline 0.18 & 0.20 & 48.15 & - & - & - & Iran $[8]$ \\
\hline 1 & - & 116.04 & 0.74 & - & 42.00 & Egypt [9] \\
\hline 0.075 & 0.012 & - & 0.027 & 0.001 & - & China [10] \\
\hline- & - & 74.30 & - & - & 52.90 & Lebanon [11] \\
\hline 0.049 & 0.001 & 68.39 & 0.009 & 0.001 & 20.94 & Korea [12] \\
\hline 0.51 & 1.33 & 57.64 & 0.46 & 1.62 & 69.88 & India [13] \\
\hline 1.90 & 2.40 & 80.30 & - & - & - & India [14] \\
\hline 2.60 & 2.92 & 163.40 & 1.30 & 1.56 & 111.00 & Italy [15] \\
\hline 7.67 & 20.24 & 75.47 & 8.15 & 32.30 & 75.55 & Indonesia [16] \\
\hline 1.22 & 1.95 & 1190.45 & 1.61 & 1.22 & 439.53 & Malaysia [17] \\
\hline 48.80 & 25.36 & 1017.94 & - & - & - & Malaysia [18] \\
\hline $\begin{array}{c}0.049- \\
8.80\end{array}$ & $\begin{array}{l}0.001- \\
25.36\end{array}$ & $\begin{array}{c}0.79- \\
1190.45\end{array}$ & $\begin{array}{l}0.009- \\
8.15\end{array}$ & $\begin{array}{l}0.001- \\
32.30\end{array}$ & $\begin{array}{l}20.94- \\
439.53\end{array}$ & $\begin{array}{l}\text { Range of previous study } \\
\text { [6-18] }\end{array}$ \\
\hline 2.07 & 2.12 & 791.51 & 2.44 & 1.54 & 288.63 & Present study \\
\hline
\end{tabular}


Table 4. Calculated ingestion dose, $D$ from the intake of ${ }^{226} \mathrm{Ra},{ }^{232} \mathrm{Th}$ and ${ }^{40} \mathrm{~K}$ in vegetables and fruits for three age categories

\begin{tabular}{|c|c|c|c|c|c|}
\hline \multirow{3}{*}{ Type } & \multirow{3}{*}{ Age Category } & \multicolumn{4}{|c|}{ Ingestion Dose $(\mathrm{mSv} / \mathrm{y})$} \\
\hline & & \multicolumn{3}{|c|}{$D \pm \Delta D$} & \multirow{2}{*}{$D_{T}^{ \pm} \Delta D_{T}{ }^{(a)}$} \\
\hline & & ${ }^{226} \mathbf{R a}$ & ${ }^{232} \mathrm{Th}$ & ${ }^{40} \mathbf{K}$ & \\
\hline \multirow[t]{3}{*}{ Vegetables } & Infants & $0.026 \pm 0.004$ & $0.012 \pm 0.001$ & $0.431 \pm 0.002$ & $0.469 \pm 0.003$ \\
\hline & Children & $0.043 \pm 0.006$ & $0.016 \pm 0.002$ & $0.267 \pm 0.001$ & $0.326 \pm 0.005$ \\
\hline & Adults & $0.023 \pm 0.003$ & $0.019 \pm 0.002$ & $0.191 \pm 0.001$ & $0.232 \pm 0.003$ \\
\hline \multirow[t]{3}{*}{ Fruits } & Infants & $0.054 \pm 0.008$ & $0.016 \pm 0.003$ & $0.279 \pm 0.003$ & $0.349 \pm 0.005$ \\
\hline & Children & $0.090 \pm 0.013$ & $0.021 \pm 0.003$ & $0.173 \pm 0.002$ & $0.283 \pm 0.007$ \\
\hline & Adults & $0.047 \pm 0.007$ & $0.024 \pm 0.004$ & $0.124 \pm 0.001$ & $0.195 \pm 0.004$ \\
\hline
\end{tabular}

Upon comparing these two values, it was found that for vegetables: (a), the $D$ due to intake of ${ }^{226} \mathrm{Ra}$ and ${ }^{232} \mathrm{Th}$ for three age categories were below the UNSCEAR annual ingestion dose. Hence, it was automatically below the annual radiation dose from natural sources, (b) only the $D$ due to intake of ${ }^{40} \mathrm{~K}$ for children and adults were below the UNSCEAR annual ingestion dose, whereas for infants, the $D$ value were higher. However, it is still below the value of annual radiation dose from natural sources, (c) the $D$ due to total intake of three radionuclides for infants and children are higher than the UNSCEAR annual ingestion dose by a factor of 1.57 and 1.04 respectively, however they are still below the value of annual radiation dose from natural sources.

The comparison results for fruits: (a) the $D$ due to intake of ${ }^{226} \mathrm{Ra},{ }^{232} \mathrm{Th}$ and ${ }^{40} \mathrm{~K}$ for three age categories were below the UNSCEAR annual ingestion dose. Hence, it was automatically below the annual radiation dose from natural sources, (b) the $D$ due to total intake of three radionuclides were also below the UNSCEAR annual ingestion dose except for infants (higher by a factor of 1.08). However, it is still below the value of annual radiation dose from natural sources. To provide a better understanding of these results, the dose comparison were shown in Figure 1.

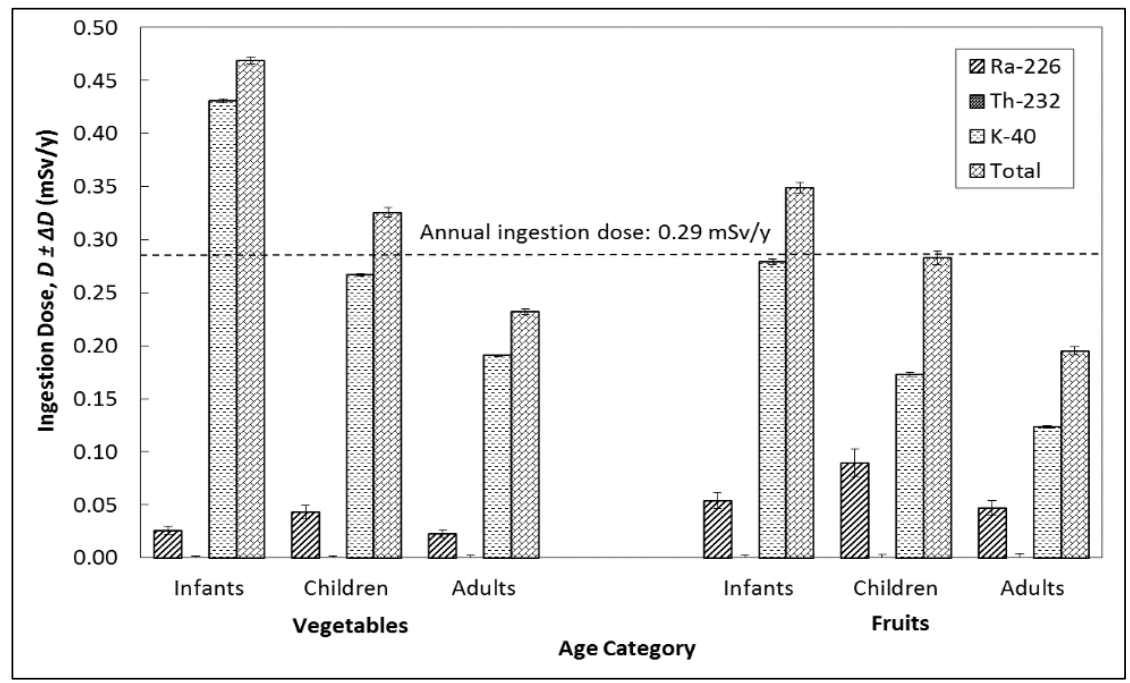

Figure 1. Ingestion dose of infants, children and adults from the intake of radionuclides ${ }^{226} \mathrm{Ra},{ }^{232} \mathrm{Th}$ and ${ }^{40} \mathrm{~K}$ in vegetables and fruits. The dose contributed by ${ }^{232} \mathrm{Th}$ is in the range of $0.012-0.019 \mathrm{mSv} / \mathrm{y}$ for vegetables and $0.016-0.024 \mathrm{mSv} / \mathrm{y}$ for fruits, therefore they hardly can be seen. 


\section{Priharti et al: RADIOLOGICAL RISK ASSESSMENT FROM THE INTAKE OF VEGETABLES AND FRUITS IN MALAYSIA}

The $D$ for infants and children for both vegetables and fruits were found to be higher than adults despite the lower value of intake $I$ (Table 1). This is due to the higher value of $E$ (ingestion dose conversion factor) for each radionuclide. The $E$ value for infants were found to be higher by adults in the range of $1.96-6.77$, whereas for children in the range of $1.26-2.86$. Following the formula of $D=A \times I \times E$, for the same $A$, it makes sense that the $D$ is higher when the $E$ is higher.

The cancer risk $R$ of $8.13 \times 10^{-4}$ and $6.83 \times 10^{-4}$ were estimated corresponding to the adult total ingestion dose of 0.232 and $0.195 \mathrm{mSv} / \mathrm{y}$ for vegetables and fruits respectively. These risk are significantly lower than the risk estimated by UNSCEAR from total natural radiation dose of $2.4 \mathrm{mSv} / \mathrm{y}$ i.e. $8.4 \times 10^{-3}$. The reduction by a factor of 10.34 and 12.31 respectively for vegetables and fruits deduces that the vegetables and fruits in Malaysia are safe for human consumption.

Another approach from Cohen and Lee [32] were also used to estimate the health risk posed from the intake of vegetables and fruits. The avoid confusion, these authors estimated the health risk in terms of day loss. It is estimated that an average loss of 9.9 days from continuos exposure of $1 \mathrm{mSv} / \mathrm{y}$ throughout life. Based on the total dose of 0.215 and $0.159 \mathrm{mSv} / \mathrm{y}$, the estimated life expectancy for adults is shorten by only 2.13 and 1.57 days due to the consumption of vegetables and fruits respectively. It is therefore concluded that the vegetables and fruits consumed by Malaysian population would not pose any significant radiological impact on health and cancer risk to the population.

\section{Conclusion}

The ingestion dose due to the activity concentration of ${ }^{226} \mathrm{Ra},{ }^{232} \mathrm{Th}$ and ${ }^{40} \mathrm{~K}$ in vegetables and fruits in Malaysia were found to be below natural radiation exposure reported by UNSCEAR. It was also comparable to published value reported by other researchers. The estimated risk has no significant health hazard as they were also below the UNSCEAR cancer risk factor. Therefore, it is concluded that the vegetables and fruits available in Malaysia are radiologically safe for human consumption. The data reported here will provide a baseline radiometric values for natural radionuclides in vegetables and fruits and also the radiological risk indices associating with them.

\section{References}

1. IAEA (2004). Radiation, people and the environment : A broad view of ionising radiation, its effects and uses as well as the measures in place to it safely. Vienna: International Atomic Energy Agency: pp. 14.

2. UNSCEAR (2000). Sources and effects of ionizing radiation. New York: United Nations: pp. 140.

3. Khan, H., Chaudhry, Z., Ismail, M. and Khan, K. (2010). Assessment of radionuclides, trace metals and radionuclide transfer from soil to food of Jhangar Valley (Pakistan) using gamma-ray spectrometry. Water, Air, \& Soil Pollution, 213(1-4): $353-362$.

4. Othman, K. I., Karim, M. S. A., Karim, R., Adzhan, N., Halim, N. A. and Osman, S. (2012). Factors influencing fruits and vegetables consumption behaviour among adults in Malaysia. Journal of Agribusiness Marketing, 5: 29 - 46.

5. Ministry of Health (2010). Malaysian dietary guidelines. Putrajaya: Ministry of Health Malaysia. pp. 1 - 4.

6. Hernández, F., Hernández-Armas, J., Catalán, A., Fernández-Aldecoa, J. C. and Landeras, M. I. (2004). Activity concentrations and mean annual effective dose of foodstuffs on the island of Tenerife, Spain. Radiation Protection Dosimetry, 111(2): 205 - 210.

7. Al-Masri, M. S., Mukallati, H., Al-Hamwi, A., Khalili, H., Hassan, M., Assaf, H., Amin, Y. and Nashawati, A. (2004). Natural radionuclides in Syrian diet and their daily intake. Journal of Radioanalytical and Nuclear Chemistry, 260(2): $405-412$.

8. Hosseini, T., Fativand, A. A., Barati, H. and Karimi, M. (2006). Assessment of radionuclides in imported foodstuffs in Iran. International Journal of Radiation Research, 4(3): 149 - 153.

9. Saleh, I .H., Hafez, A. F., Elanany, N. H., Motaweh, H. A. and Naim, M. A. (2007). Radiological study on soils, foodstuff and fertilizers in the Alexandria region, Egypt. Turkish Journal of Engineering \& Environmental Sciences, 31(1): 9 - 17.

10. Quan, W., Hongda, Z., Tiqiang, F. and Qingfen, L. (2008). Re-estimation of internal dose from natural radionuclides for Chinese adult men. Radiation Protection Dosimetry, 130(4): 434 - 441. 
11. Nasreddine, L., El Samad, O., Hwalla, N., Baydoun, R., Hamzé, M. and Parent-Massin, D. (2008). Activity concentrations and mean annual effective dose from gamma-emitting radionuclides in the Lebanese diet. Radiation Protection Dosimetry, 131(4): 545 - 550.

12. Choi, M. S., Lin, X. J., Lee, S. A., Kim, W., Kang, H. D., Doh, S. H., Kim, D. S. and Lee, D. M. (2008). Daily intakes of naturally occurring radioisotopes in typical Korean foods. Journal of Environmental Radioactivity, 99(8): 1319 - 1323.

13. Shanthi, G., Kumaran, J. T. T., Gnana Raj, G. A. and Maniyan, C. G. (2009). Natural radionuclides in the South Indian foods and their annual dose. Nuclear Instruments and Methods in Physics Research Section A: Accelerators, Spectrometers, Detectors and Associated Equipment, 619(1-3): 436 - 440.

14. Khandaker, M. U., Jojo, P. J. and Kassim, H. A. (2012). Determination of primordial radionuclides in natural samples using HPGe gamma-ray spectrometry. APCBEE Procedia, 1: 187 - 192.

15. Desideri, D., Meli, M., Roselli, C., Forini, N., Rongoni, A. and Feduzi, L. (2014). Natural radionuclides in Italian diet and their annual intake. Journal of Radioanalytical and Nuclear Chemistry, 299(3): 1461 - 1467.

16. Syarbaini, S., Warsona, A. and Iskandar, D. (2014). Natural radioactivity in some food crops from BangkaBelitung islands, Indonesia. Atom Indonesia, 40(1): 27 - 32.

17. Tawalbeh, A. A. (2013). Radiological impact of naturally occurring radionuclides from dietary intakes of adults in central zone of Malaysian Peninsular. School of Applied Physics. Bangi: Universiti Kebangsaan Malaysia.

18. Saeed, M. A., Zainal, N. J., Hossain, I., Javed, M. A. and Mubarak, A. A. (2014). Measurements of natural radionuclides in vegetables by gamma spectrometry. Journal of Applied Spectroscopy 81(3): 541 - 545.

19. Priharti, W., Samat, S. B., Yasir, M. S. and Garba, N. N. (2015). Assessment of radiation hazard indices arising from natural radionuclides content of powdered milk in Malaysia. Journal of Radioanalytical and Nuclear Chemistry, 307(1): 297 - 303.

20. Priharti, W., Samat, S. B. and Yasir, M. S. (2015). Measurement of natural radionuclides in Malaysian bottled mineral water and consequent health risk estimation. AIP Conference Proceedings, 1678: 040012.

21. IAEA (1989). Measurement of radionuclides in food and the environment: A guidebook technical reports No. 295. Vienna: International Atomic Energy Agency: pp. 56 - 69.

22. Samat, S. B. and Priharti, W. (2015). Determination of fano factor and pre-amplifier noise from the measurement of energy resolution of a HPGe detector. Sains Malaysiana, 44(5): 761 - 764.

23. Samat, S. B. and Evans, C. J. (1992). Statistics and nuclear counting: Theory, problems and solutions. Selangor: Universiti Pertanian Malaysia.

24. Currie, L. A. (1968). Limits for qualitative detection and quantitative determination. Analytical Chemistry, 40(3): 586 - 693.

25. Alamoudi, Z. M. (2013). Assessment of natural radionuclides in powdered milk consumed in Saudi Arabia and estimates of the corresponding annual effective dose. Journal of American Science, 9(6): 267 - 273.

26. Ministry of Health (2006). Food consumption statistics for central zone for adult population aged 18-59 years. Putrajaya: Ministry of Health Malaysia: pp. 165 - 174.

27. ICRP (2012). Compendium of Dose Coefficients based on ICRP Publication 60: ICRP Publication 119. Oxford: Pergamon Press: pp. 71 - 86.

28. IAEA (1988). Facts about low-level radiation. Vienna: International Atomic Energy Agency.

29. Lilley, J. S. (2001). Nuclear physics principle and applications. England: John Wiley \& Sons Inc.

30. Badran, H. M., Sharshar, T. and Elnimer, T. (2003). Levels of 137Cs and 40K in edible parts of some vegetables consumed in Egypt. Journal of Environmental Radioactivity, 67(3): 181 - 190.

31. Chibowski, S. (2000). Studies of radioactive contaminations and heavy metal contents in vegetables and fruit from Lublin, Poland. Polish Journal of Environmental Studies, 9(4): 249 - 253.

32. Cohen, B. L. and Lee, I. S. (1991). Catalog of risks extended and updated. Health Physics, 61: 317 -335. 